\title{
Parental knowledge and metabolic control of children and young adults with type 1 diabetes
}

\author{
Anna Stefanowicz ${ }^{1,2}$, Malgorzata Mysliwiec ${ }^{2}$, Elzbieta Adamkiewicz-Drozynska ${ }^{3}$
}

\begin{abstract}
${ }^{1}$ Advanced Registered Nurse Practitioner, Department of General Nursing, Chair of Nursing, Faculty of Health Sciences with Subfaculty of Nursing and Institute of Maritime and Tropical Medicine, Medical University of Gdansk, Gdansk, Poland ${ }^{2}$ Chair and Clinics of Pediatrics, Diabetology and Endocrinology, Medical University of Gdansk, Gdansk, Poland

${ }^{3}$ Chair and Clinics of Pediatrics, Hematology and Oncology, Medical University of Gdansk, Gdansk, Poland
\end{abstract}

Submitted: 2 May 2015

Accepted: 20 July 2015

Arch Med Sci 2018; 14, 1: 52-59

DOI: $10.5114 /$ aoms.2015.53832

Copyright $\odot 2016$ Termedia \& Banach

\section{Abstract}

Introduction: The authors aimed to answer the following questions: 1) What level of knowledge of type 1 diabetes do the parents of children and young adults with this disease have? 2) Will this level of knowledge increase after 1 year of observation? 3) Does improving the knowledge of young adults and their parents result in better metabolic control of the patients?

Material and methods: This study included 227 patients between the ages of 5 and 20 years with type 1 diabetes. The research was conducted from March 2009 to June 2011. The following two time points were examined: the beginning of the study (test 1a) and one year later (test $1 \mathrm{~b}$ ). The knowledge levels of the patients and parents were obtained using a survey and a knowledge test.

Results: Comparison of the results from the two study time points showed that the respondents had a significantly higher level of knowledge after 1 year $(p=0.001)$. The comparison of glycated hemoglobin levels between the two time points in patients with type 1 diabetes revealed that the levels were significantly higher at test $1 \mathrm{~b}$ compared to test $1 \mathrm{a}(p=0.0005)$.

Conclusions: The parents of children and young adults with type 1 diabetes demonstrate a satisfactory level of theoretical knowledge of therapeutic conduct and self-monitoring principles. The test $1 b$ results demonstrated a higher level of theoretical knowledge in all respondents and poorer metabolic control. Poorer metabolic control in some patients suggests that metabolic control in type 1 diabetes depends on factors other than education. Further research is necessary to determine these additional factors.

Key words: children, education of patients, type 1 diabetes mellitus, young adult.

\section{Introduction}

Type 1 diabetes is the most common chronic childhood disease. The treatment goal for type 1 diabetes is to achieve good metabolic control by maintaining normal levels of blood glucose, glycated hemoglobin $\left(\mathrm{HbA}_{1 c}\right)$, blood pressure, lipid parameters and body weight, while avoiding hypoglycemia. In treating children, adolescents and young adults with type 1 diabetes, an additional goal is to achieve and maintain proper and

\author{
Corresponding author: \\ Anna Stefanowicz MD, PhD \\ Advanced Registered \\ Nurse Practitioner \\ Department of General \\ Nursing \\ Chair of Nursing, Faculty \\ of Health Sciences \\ with Subfaculty of Nursing \\ and Institute of Maritime \\ and Tropical Medicine \\ Medical University of Gdansk \\ 7 Dębinki St \\ Gdansk, Poland \\ E-mail: ania-stefanowicz@ \\ gumed.edu.pl
}


healthy physical development, as well as a normal pubertal course (i.e., age and gender appropriate), while ensuring a good quality of life for the patients and their families [1].

The aim of metabolic control is to maintain $\mathrm{HbA}_{1 \mathrm{c}}$ levels at $\leq 6.5 \%$, with stable blood glucose levels, while minimizing hypoglycemia. This process helps to prevent the occurrence of acute and chronic complications and allows patients to lead normal and active family, work and social lives [1].

Children and adolescents with type 1 diabetes and their caregivers should actively participate in the treatment process. The treatment of type $1 \mathrm{di}$ abetes includes adequate insulin therapy, proper nutrition, physical activity, health education and self-care performed by the patients [1-3].

Diabetes education is a continual, integral and crucial component of the therapeutic treatment of diabetes and also helps to ensure the success of all other therapeutic methods. All patients in the developmental stage who are diagnosed with type 1 diabetes and their parents have the right to comprehensive and professional education that should prepare them to take control of diabetes [1, 4-9].

However, diabetes education should be individualized and realistic $[10,11]$. To be effective, diabetes education should be a continuous, repetitive and structured process. A systematic educational program should be subject to external evaluation, and trained educators should ensure the quality of its implementation $[12,13]$.

Continuous education is usually conducted in an outpatient setting (clinic, local community), but it is also available in hospitals. Education can occur in individual and/or group learning settings and should address the issues of self-monitoring and psychosocial concerns. Continuous educational programs should also include interactive education tools that are available to sick children and adolescent patients [14-18].

Patients and their families should also be taught how to observe, monitor and recognize the symptoms of a lack of metabolic control [19]. Diabetes self-monitoring involves determining the concentrations of glucose and ketone bodies in blood and urine, measuring blood pressure and body weight systematically, observing symptoms of hypoglycemia and hyperglycemia, self-monitoring of foot health, keeping a self-monitoring log book, and undergoing regular check-ups at a diabetes clinic. One of the basic and most important elements of self-monitoring is to self-monitor and record blood glucose levels.

The principles of proper patient education have been integrated in children's diabetes centers for several years [1]. Periodic assessments of the knowledge of parents and caregivers may play a role in determining and addressing knowledge gaps. Moreover, treatment results are greatly influenced by how well these therapeutic programs address the needs of patients and their caregivers. Therefore, it is important to assess the current knowledge of parents of children and young adults with type 1 diabetes and its impact on the degree of metabolic control.

The aim of this work was to answer the following questions.

- What level of knowledge of type 1 diabetes do the parents of children and young adults with this disease have?

- Will this level of knowledge increase after 1 year of observation?

- Does improving the knowledge of young adults and their parents result in better metabolic control of the patients?

\section{Material and methods}

In addition to their parents, this study included 227 patients with type 1 diabetes who were under the care of the Department of Pediatric Diabetology and the Diabetes Clinic for Children at the University Clinical Centre in Gdansk. The research was conducted at the following two time points (with the same patients): at the beginning of the study (test $1 \mathrm{a}$ ) and 1 year later (test $1 \mathrm{~b}$ ).

The results were based on the analysis of the authors' questionnaire, which was completed by the young adults and, in the case of children, by their parents. The questionnaires were collected from March 2009 to June 2011. The study included patients who visited the department or clinic to obtain specialist advice. All respondents agreed to participate in the study.

The survey, which consisted of two parts, was administered to the parents of children up to 18 years of age and to patients over 18 years of age. The first part included questions on basic demographic data, disease duration and date of the last training. The second part tested theoretical knowledge of type 1 diabetes. The test contained 18 test questions, each with one correct answer, concerning the nature of the disease, basic treatment principles and occurrence of metabolic disorders and complications (Table I).

The serum $\mathrm{HbA}_{1 \mathrm{c}}$ levels recorded in the patients' medical records were analyzed as the main criterion of carbohydrate metabolism control in type 1 diabetes. According to the criteria provided by the Polish Diabetes Association, $\mathrm{HbA}_{1 \mathrm{c}}$ levels $\leq 6.5 \%$ are regarded as good metabolic control [1]. An $\mathrm{HbA}_{1 \mathrm{c}}$ level of $7.5 \%$ was used as the value to divide the respondents into 2 groups, one with average metabolic control and the other with poor control. 
Table I. Issues included in the test evaluating the level of knowledge of parents and young adults about type 1 diabetes [20]

\begin{tabular}{|lr|}
\hline $\begin{array}{l}\text { Number of the } \\
\text { question }\end{array}$ & Issues included in the test \\
\hline 1 & The concept of diabetes of insulin synthesis \\
\hline 2 & Basic principles of healthy nutrition \\
\hline $3,4,5,6,8$ & $\begin{array}{r}\text { The definition of a carbohydrate unit } \\
\hline 7\end{array}$ \\
\hline $9,10,11,12$ & $\begin{array}{r}\text { The role of exercise in the treatment } \\
\text { and the principles of taking it up }\end{array}$ \\
\hline 13 & $\begin{array}{r}\text { The knowledge of acute metabolic } \\
\text { disorders }\end{array}$ \\
\hline 14,15 & $\begin{array}{r}\text { The interpretation of the } \\
\text { measurement results of glucose } \\
\text { concentration in capillary blood }\end{array}$ \\
\hline 16 & $\begin{array}{r}\text { Indications for glucagon } \\
\text { administration }\end{array}$ \\
\hline 18 & $\begin{array}{r}\text { Symptoms of hyperglycemia } \\
\hline\end{array}$
\end{tabular}

Furthermore, selected clinical patient data evaluating the length and nutritional status of each child were analyzed. The nutritional status of the patients was assessed based on the length and weight measurements and the body mass index (BMI) analysis. Growth charts compiled by the Polish National Research Project OLAF were used to analyze the nutritional status of the children $[20,21]$.

\section{Statistical analysis}

Statistica PL 10 was used for the data analysis. The results are presented as the arithmetic mean and median, and the dispersion of the results was assessed with the standard deviation as well as the minimum and maximum values.

Statistical inference was performed depending on the scale type and the distribution of the results using nonparametric methods. To analyze the results of the variables from the nominal scale, tabulation and a $\chi^{2}$ test were used; Pearson's correlation analysis was used for the variables from the quantitative scale.

To verify the significance of differences between the studies, the McNemar test was used. To compare between-group differences, the MannWhitney $U$ test (a non-parametric equivalent of Student's t-test for unpaired variables) or the Kruskal-Wallis one-way analysis of variance by ranks (non-parametric equivalent for the analysis of variance) was used. To determine statistically significant differences between two or more groups, post hoc tests were used for non-parametric analyses, and $p<0.05$ was considered significant.

\section{Results}

At time points $1 \mathrm{a}$ and $1 \mathrm{~b}$ there were 104 (45.8\%) and 79 (42.7\%) male patients and 123 (54.2\%) and 106 (57.3\%) female patients, respectively. The study included patients between 5 and 20 years of age, among whom 144 (63.4\%) lived in urban areas, and 83 (36.6\%) lived in rural areas. The patients had been treated for type 1 diabetes for 3 to 17 years, and the mean disease duration was 6.6 years.

The patients underwent two different methods of insulin therapy. At time points $1 \mathrm{a}$ and $1 \mathrm{~b}$, the majority of children (174/227 (77\%) and 147/185 (79.5\%), respectively) were treated with continuous subcutaneous insulin infusion (CSII). The remaining patients (53/227 (23\%) and 38/185 (20.5\%), respectively) received insulin using an insulin pen. The patient characteristics are shown in Table II.

Knowledge levels were assessed using a test that contained 18 questions concerning the nature of the disease and the basic principles of treatment, metabolic disorders and complications.

Table II. General characteristics of the population in tests $1 \mathrm{a}$ and $1 \mathrm{~b}$

\begin{tabular}{|c|c|c|c|c|c|c|}
\hline Parameter & \multicolumn{3}{|c|}{ Test $1 \mathrm{a}$} & \multicolumn{3}{|c|}{ Test $1 \mathrm{~b}$} \\
\hline Gender (M/F) & \multicolumn{3}{|c|}{$104 / 123(45.8 \% / 54.2 \%)$} & \multicolumn{3}{|c|}{ 79/106 (42.7\%/57.3\%) } \\
\hline $\begin{array}{l}\text { Place of residence } \\
(R / U)\end{array}$ & \multicolumn{3}{|c|}{$83 / 144(36.6 \% / 63.4 \%)$} & \multicolumn{3}{|c|}{ 72/113 (38.9\%/61.1\%) } \\
\hline Parameter & Mean \pm SD & Median & $\begin{array}{l}\text { Minimum - } \\
\text { maximum }\end{array}$ & Mean \pm SD & Median & $\begin{array}{l}\text { Minimum - } \\
\text { maximum }\end{array}$ \\
\hline Age [years] & $13.5 \pm 3.4$ & 14 & $5-19$ & $14.4 \pm 3.5$ & 15 & $6-20$ \\
\hline $\begin{array}{l}\text { Disease duration } \\
\text { [years] }\end{array}$ & $6.6 \pm 3.1$ & 6 & $3-17$ & & & \\
\hline $\begin{array}{l}\text { Elapsed time since last } \\
\text { training [years] }\end{array}$ & $4.3 \pm 3.3$ & 3.25 & $0.5-17$ & $3.1 \pm 2.8$ & 2 & $0.5-15$ \\
\hline $\begin{array}{l}\text { Treatment method } \\
\text { (pen/CSII) }\end{array}$ & \multicolumn{3}{|c|}{$53 / 174(23.3 \% / 76.7 \%)$} & \multicolumn{3}{|c|}{$38 / 147$ (20.5\%/79.5\%) } \\
\hline
\end{tabular}


Each question had one correct answer for which the parents and young adults received one point, and the maximum score was 18 points.

A detailed test analysis showed that in tests $1 \mathrm{a}$ and $1 \mathrm{~b}$, the most difficult questions were 3 and 13. Question 3 related to the basic principles of rational nutrition, and question 13 related to acute metabolic disorders in type 1 diabetes.

After 1 year, there were more correct responses regarding the definition of a bread unit (BU), the principles of healthy nutrition, the indications for glucagon administration, and the symptoms of hyperglycemia, whereas there were fewer correct answers regarding acute metabolic disorders (Table III).

Analysis of the length and weight measurements and $\mathrm{BMI}$ values at time points $1 \mathrm{a}$ and $1 \mathrm{~b}$ are shown in Table IV.

The knowledge level, metabolic control (based on $\mathrm{HbA}_{1 \mathrm{c}}$ values), and occurrence of nutritional status disorders were compared between time points $1 \mathrm{a}$ and $1 \mathrm{~b}$. The results indicated that the respondents had a significantly higher level of knowledge at time point 2 (mean \pm SD: $14.1 \pm 2.6$ vs. $14.8 \pm 2, p=0.001$, Figure 1 ).

The results also showed that the $\mathrm{HbA}_{1 \mathrm{c}}$ levels were significantly higher at time point $1 \mathrm{~b}$ compared with time point 1 a (mean \pm SD: $8.7 \pm 1.9$ vs. $8.55 \pm 1.8, p=0.0005$; Figure 2).

The occurrence of nutritional status disorders was compared between time points $1 \mathrm{a}$ and $1 \mathrm{~b}$. At both time points, the incidence of overweight and obese body status was comparable (Table V).

\section{Discussion}

Type 1 diabetes is one of the most common incurable chronic diseases occurring during development.

The aim of diabetes treatment is to achieve metabolic control, reduce the occurrence of diabetic ketoacidosis and severe hypoglycemia, and prevent chronic organ complications [1, 22]. In recent years, there has been a tendency to accept lower $\mathrm{HbA}_{1 \mathrm{c}}$ levels as a criterion of metabolic control in type 1 diabetes. One study conducted at 305 centers in Germany and Austria between 1995 and 2009 showed significant improvement in metabolic control in children and adolescents with type 1 diabetes and a simultaneous decrease in hypoglycemic events. These authors emphasized that this improvement was achieved using modern therapy methods and improved education methods for the patients and their families [23].

According to the latest recommendations of the American Diabetes Association, when treating toddlers and preschoolers ( $0-6$ years old) with type 1 diabetes, the goal should be to achieve and maintain $\mathrm{HbA}_{1 \mathrm{c}}$ levels < 8.5\%, compared to $<8.0 \%$ for school children (6-12 years) and $<7.5 \%$ for adolescents and young adults (13-19 years), while simultaneously preventing episodes of severe hypoglycemia [22].

The 2012 recommendations of the International Society for Pediatric and Adolescent Diabetes

Table III. Assessment of the degree of difficulty of particular questions in the test (based on the number of correct answers given) at time points $1 \mathrm{a}$ and $1 \mathrm{~b}$

\begin{tabular}{|lccc|}
\hline Question no. & Question content & $\begin{array}{c}\text { Percent of correct } \\
\text { answers in test 1a }\end{array}$ & $\begin{array}{c}\text { Percent of correct } \\
\text { answers in test 1b }\end{array}$ \\
\hline 3 & The principles of healthy nutrition & 26.4 & 39.5 \\
\hline 7 & The definition of BU & 90.8 & 96.2 \\
\hline 13 & Acute metabolic disorders & 22.5 & 15.7 \\
\hline 17 & Indications for glucagon administration & 94.7 & 97.3 \\
\hline 18 & Symptoms of hyperglycemia & 92.5 & 97.3 \\
\hline
\end{tabular}

Table IV. Body weight and height and BMI values in the study population in tests $1 \mathrm{a}$ and $1 \mathrm{~b}$

\begin{tabular}{|lcccc|}
\hline $\begin{array}{l}\text { Time point } \\
\text { of the study }\end{array}$ & Parameter & Mean \pm SD & Median & $\begin{array}{c}\text { Minimum - } \\
\text { maximum }\end{array}$ \\
\hline Test 1a & Body height $[\mathrm{cm}]$ & $158.9 \pm 18.4$ & 162.5 & $91-191$ \\
\cline { 2 - 5 } & Body weight $[\mathrm{kg}]$ & $51.7 \pm 17$ & 51.6 & $13-95$ \\
\cline { 2 - 5 } & BMI $\left[\mathrm{kg} / \mathrm{m}^{2}\right]$ & $19.8 \pm 3.4$ & 19.7 & $11.9-32.5$ \\
\hline Test 1b & Body height $[\mathrm{cm}]$ & $161.6 \pm 17.5$ & 165 & $91-193$ \\
\cline { 2 - 5 } & Body weight $[\mathrm{kg}]$ & $54.7 \pm 17.2$ & 56.3 & $14.4-99.7$ \\
\cline { 2 - 5 } & BMI $\left[\mathrm{kg} / \mathrm{m}^{2}\right]$ & $20.3 \pm 3.4$ & 20.1 & $13.2-33.1$ \\
\hline
\end{tabular}




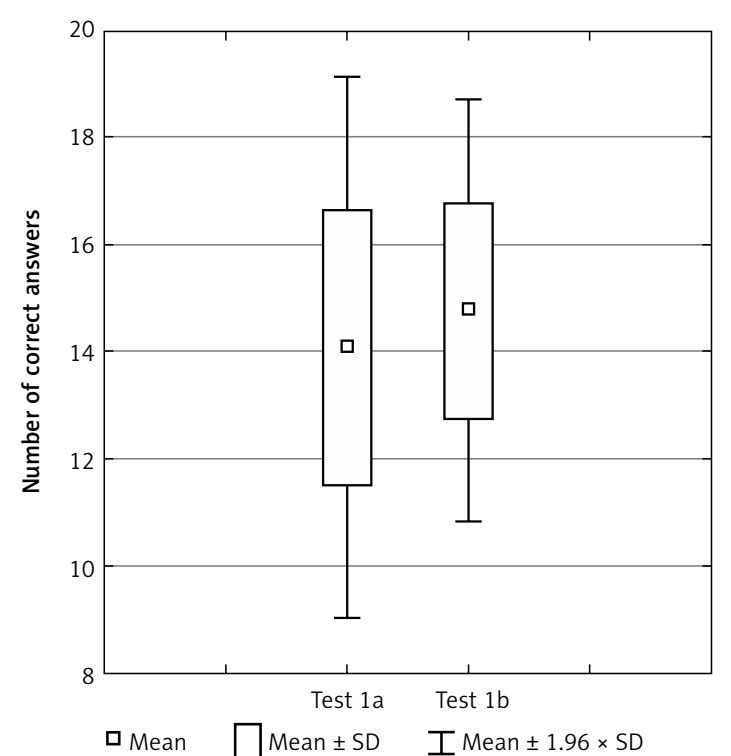

Figure 1. Comparison of the level of knowledge in tests $1 \mathrm{a}$ and $1 \mathrm{~b}$

Table V. Comparison of nutritional status disorders in tests $1 \mathrm{a}$ and $1 \mathrm{~b}$

\begin{tabular}{|lcc|}
\hline Nutritional status & Test $1 \mathrm{a}, \boldsymbol{n}(\%)$ & Test $\mathbf{1 b}, \boldsymbol{n}(\%)$ \\
\hline Normal weight & $138(78.8)$ & $139(79.4)$ \\
\hline Overweight & $26(14.9)$ & $24(13.7)$ \\
\hline Obesity & $3(1.7)$ & $5(2.9)$ \\
\hline Underweight & $8(4.6)$ & $7(4)$ \\
\hline
\end{tabular}

(ISPAD) include a target $\mathrm{HbA}_{1 \mathrm{c}}$ of $\leq 7.5 \%$ [24]. According to the recommendations of the Polish Diabetes Association, an $\mathrm{HbA}_{1 \mathrm{c}}$ level $\leq 6.5 \%$ serves as a detailed criterion of carbohydrate metabolism control in type 1 diabetes in children and adolescents; however, it is difficult to achieve this goal [1]. Indeed, many authors in Poland state that such values of $\mathrm{HbA}_{1 \mathrm{c}}$ values are achieved by only a small number of patients [25].

The current study included patients who reported to the clinic and/or department with specific therapeutic problems. Thus, these results should not be related to or interpreted as the treatment results of the overall population of children treated at the center in which the study was conducted.

In the present study, only 5 (2.2\%) children achieved $\mathrm{HbA}_{1 \mathrm{c}}$ values $\leq 6.5 \%$. Thus, for the purposes of statistical analysis, the test group was divided into two groups: one with average control and the other with poor control, using an $\mathrm{HbA}_{1}$ value of $7.5 \%$ as the criterion of division to divide the groups.

At time points $1 \mathrm{a}$ and $1 \mathrm{~b}$, the mean $\mathrm{HbA}_{1 \mathrm{c}}$ values were $8.55 \pm 1.8 \%$ and $8.7 \pm 1.9 \%$, respectively



Figure 2. Comparison of glycated hemoglobin values in tests $1 \mathrm{a}$ and $1 \mathrm{~b}$

$(p=0.0005)$. The patients with average control $\left(\mathrm{HbA}_{1 \mathrm{c}} \leq 7.5 \%\right)$ accounted for $29 \%$ of the patients evaluated at time point $1 \mathrm{a}$ and $27.7 \%$ at time point $1 \mathrm{~b}$.

Similar $\mathrm{HbA}_{1 c}$ values were demonstrated in patients with type 1 diabetes by researchers at the University of Bergen [26]. In addition, a multicenter collaborative German and Austrian study conducted from 1995 to 2009 demonstrated that the mean $\mathrm{HbA}_{1 \mathrm{c}}$ value was $8.4 \pm 1.7 \%$, which was higher than the recommended target of $7.5 \%$ [23].

One important aspect of treatment is the education of the patient and their relatives, which should prepare the patient for appropriate self-monitoring, thus ensuring the best possible metabolic control and a reduced risk of future microvascular disease $[27,28]$. In this study, test questions were used to assessed the knowledge of the parents of children and young adults with type 1 diabetes. The demonstrated level of knowledge was considered good. At time point $1 \mathrm{a}$, the average test result was $14.1 \pm 2.6$, whereas it was $14.8 \pm 2$ at time point $1 \mathrm{~b}$, which was significantly higher.

Pietrzak and Bodalski showed that the level of the patients' knowledge and practical skills were positively correlated with the children's age, education and intelligence levels. The authors also found that patients characterized as having good metabolic control demonstrated a higher level of knowledge than those with worse metabolic control [29].

It is believed that insulin therapy in patients with type 1 diabetes may result in excessive weight gain in some cases. Moreover, obesity in individuals diagnosed with type 1 diabetes may be an additional risk factor for cardiovascular disease 
$[30,31]$. According to the literature, the following factors are the most relevant for the development of obesity: no energy loss through urine with improved glycemic control; the anabolic effect of insulin; an increased intake of high-energy meals caused by the fear of hypoglycemia; the non-physiological, subcutaneous method of insulin administration; and the effect of insulin on the appetite center in the central nervous system [31, 32].

Despite a satisfactory level of knowledge demonstrated by the patients, nutritional disorders were observed, including obesity in 3\% of cases and overweight status in $14 \%$ of cases. The present study also assessed the nutritional status of children with type 1 diabetes. The mean BMI value at time point 1 a was $19.8 \pm 3.4 \mathrm{~kg} / \mathrm{m}^{2}$ and $20.3 \pm 3.4 \mathrm{~kg} / \mathrm{m}^{2}$ at time point $1 \mathrm{~b}$. These study results are consistent with the results of a Norwegian study [33]. In addition, Luczynski et al. assessed nutritional status disturbances in a group of 300 children treated with insulin for at least 1 year. Obesity was observed in $12 \%$ and overweight status in $15 \%$ of the patients [32].

Araszkiewicz et al. demonstrated the efficacy of educational programs and observed a link between metabolic control, the occurrence of retinopathy and albuminuria, and the patient's level of knowledge. According to the authors, improved knowledge about diabetes is the foundation for better metabolic control and can reduce the risk of complications [27]. In our studies, comparison of the knowledge levels of the parents of children and young adults with type 1 diabetes showed that after 1 year, the respondents' test results improved ( $p=0.001)$. Surprisingly, the comparison of metabolic control $\left(\mathrm{HbA}_{1 c}\right.$ concentration) at the beginning of the study and 1 year later demonstrated worse control in children over time $(p=0.0005)$. Most likely, this difference in $\mathrm{HbA}_{1 \mathrm{c}}$ values was caused by socio-psychological factors (e.g., puberty, loss of parent control, peer influence) and was not related to the level of knowledge. Therefore, the following questions arise:

- Why is the level of metabolic control unsatisfactory despite the fact that the level of knowledge is good?

- Why is the level of metabolic control worse after one year and still unsatisfactory despite the fact that the level of knowledge is higher?

- Does the level of knowledge of patients and their parents affect the level of metabolic control?

To examine the underlying causes of the discrepancy between the level of knowledge in the parents of children and young adults (which was higher) and the metabolic control of the tested patients with type 1 diabetes after 1 year (which was worse), one should also consider the individual determinants of mental health of the patients and their ability to maintain self-discipline. In addition, the support that a young patient receives in the fight against a chronic disease and a number of other factors (primarily psychological) that affect the practical implementation of theoretical knowledge during treatment should also be examined. However, these issues do not exclude the role of education in treating this disease, and properly conducted education that results in a higher level of knowledge remains an important part of diabetes treatment.

In a previous study, Brackenridge and Swenson showed that "Discovering Diabetes," a consistently led diabetes education program, influenced the metabolic control of diabetes. The Brackenridge and Swenson program used the discovery learning method, the purpose of which was to develop self-managements skills in the patients and their parents. The authors concluded that by using this program, the patients achieved a significant reduction in $\mathrm{HbA}_{1 \mathrm{c}}$ concentrations, which persisted during and after the completion of education. In particular, the mean $\mathrm{HbA}_{1 \mathrm{c}}$ concentration measured at the beginning of the program was $9.3 \%$, whereas 3 months after the program started, the level fell to $6.2 \%$ and remained at $6.6 \%$ after $22-$ 26 months.

According to the Polish Diabetes Association, education should be a continual, integral and essential component of the therapeutic approach to diabetes during each follow-up visit. Moreover, education should be implemented in a structured manner based on a general outline that includes education at the onset of therapy and then re-education based on an annual assessment of the training needs of the patient or upon request. Every educational program should also specify the program duration [1].

The aim of patient education is to support the patient in the independent management of diabetes (self-management training) and lifestyle modification associated with the recommended diet and physical activity [1]. In 2000, the CSII method was introduced for diabetes treatment. However, due to the lack of education and treatment standards for this type of insulin therapy, the "Prospective Polish Insulin Pump Therapy Programme" (OPPLP) was initiated [34]. The aim of the OPPLP was to prepare the diabetic centers in Poland for the implementation of insulin pump treatment. This program was conducted in 16 pediatric diabetic centers in two stages: 1) education and 2) clinical data collection and an evaluation of the treatment's effectiveness [35]. The OPPLP was a pilot program and one of the few programs combining the training of educators caring for children with diabetes, the assessment of the effects and quality of the treatment, and the imple- 
mentation of new technology in standard medical practice [35].

In the UK and Ireland, an educational course for patients with type 1 diabetes termed "Dose Adjustment for Normal Eating" (DAFNE) was introduced. DAFNE teaches patients to adjust their insulin doses in accordance with their nutritional status and blood glucose concentration [14, 36-38].

Many studies have shown that educational programs are a primary method of supporting the treatment of type 1 diabetes and its complications $[2,14,15,22,37,39-41]$. Currently, therapeutic education is a necessary component of treatment and is implemented together with other strategies for diabetes control.

The role of education in treating type 1 diabetes was emphasized by Rosenbauer et al., who, in a multicenter Austrian and German study, demonstrated significant improvement in the metabolic control of type 1 diabetes in children and young adults over a 10-year period. The researchers linked this improvement to insulin therapy changes, as well as improvements in education [23].

The success of a therapeutic process depends largely on the ability to perform self-management. In the case of children and young people, the patients, as well as their parents and guardians, assume the responsibility for self-management [42].

The effectiveness of treatment depends on the state of knowledge, on the conduct of sick children and young adults and their parents and caregivers, and on patient acceptance of the available methods of self-management and therapy. Indeed, it is known that apart from knowledge, human behavior is affected by a variety of psychological and social factors. Also it should be remembered that achieving good metabolic control also depends on other factors, such as type of diabetes, proper insulin therapy and appropriate self-management, nutritional status, occurrence of lipid disorders, and the presence of additional diseases, such as celiac disease, cystic fibrosis, or frequent infections $[1,43,44]$.

The main limitations of this study were as follows: 1) the use of the same questionnaire at time points $1 \mathrm{a}$ and $1 \mathrm{~b}$ (the questionnaire pattern was inadvertently made available to the respondents) and 2) the diversity of the study group, which primarily consisted of parents of children and a small number of young adults.

In conclusion, the parents of children and young adults with type 1 diabetes demonstrated a satisfactory level of theoretical knowledge of therapeutic conduct and self-management principles. The test $1 \mathrm{~b}$ results demonstrated a higher level of theoretical knowledge in all respondents but poorer metabolic control. Poorer metabolic control in some patients suggests that metabolic control in type 1 diabetes also depends on factors other than education. Further research is necessary to determine these factors.

\section{Conflict of interest}

The authors declare no conflict of interest.

\section{References}

1. Polskie Towarzystwo Diabetologiczne. Zalecenia kliniczne dotyczące postępowania u chorych na cukrzycę 2014. Diabetol Dosw Klin 2014; 2 (Suppl. A): A1-70.

2. Cradock S, Cranston C. Type 1 diabetes education and care: time for a rethink? Diab Med 2012; 29: 159-60.

3. lafusco D. Diet and physical activity in patients with type 1 diabetes. Acta Biomed 2006; 77 (Suppl. 1): 41-6.

4. George JT, Valdovinos AP, Russell I, et al. Clinical effectiveness of a brief educational intervention in type 1 diabetes: results from the BITES (Brief Intervention in Type 1 Education for Self-efficacy) trial. Diab Med 2008; 25: 1447-53.

5. Jönsson L, Hallström I, Lundqvist A. A multi-disciplinary education process related to the discharging of children from hospital when the child has been diagnosed with type 1 diabetes - a qualitative study. BMC Pediatr 2010; 10: $1-10$.

6. Kubiak T, Hermanns N, Schreckling HJ, Kulzer B, Haak T. Evaluation of a self-management-based patient education program for the treatment and prevention of hypoglycemia-related problems in type 1 diabetes. Patient Education and Counseling 2006; 60: 228-34.

7. Lange K, Sassmann H, Schütz W, Kordonouri O, Danne T. Prerequisites for age-appropriate education in type $1 \mathrm{di}$ abetes: a model programme for paediatric diabetes education in Germany. Pediatr Diab 2007; 8 (Suppl. 6): 63-71.

8. Rogers H, Turner E, Thompson G, Hopkins D, Amiel SA. Hub-and-spoke model for a 5-day structured patient education programme for people with type 1 diabetes. Diab Med 2009; 26: 915-20.

9. Viklund GE, Rudberg S, Wikblad KF. Teenagers with diabetes: self-management education and training on a big schooner. Int J Nurs Pract 2007; 13: 385-92.

10. Povlsen L, Olsen B, Ladelund S. Educating families from ethnic minorities in type 1 diabetes - experiences from a Danish intervention study. Patient Educ Couns 2005; 59: $164-70$

11. Rankin D, Heller S, Lawton J. Understanding information and education gaps among people with type 1 diabetes: a qualitative investigation. Patient Educ Couns 2011; 83: 87-91.

12. Gőbl CS, Dobes B, Luger A, Bischof M G, Krebs M. Longterm impact of a structured group-based inpatient-education program for intensive insulin therapy in patients with diabetes mellitus. Wiener Klinische Wochenschrift 2010; 122: 341-5.

13. Wang Y, Stewart SM, Mackenzie M, Nakonezny PA, Edwards D, White PC. A randomized controlled trial comparing motivational interviewing in education to structured diabetes education in teens with type 1 diabetes. Diabetes Care 2010; 33: 1741-3.

14. Chaney D. Structured diabetes education for children and adolescents. Nurs Stand 2012; 27: 41-7.

15. Chaney D, Coates V, Shevlin M, Carson D, McDougall A, Long A. Diabetes education: what do adolescents want? J Clin Nurs 2012; 21: 216-23. 
16. Konradsdottir E, Svavarsdottir EK. How effective is a short-term educational and support intervention for families of an adolescent with type 1 diabetes? J Spec Pediatr Nurs 2011; 16: 295-304.

17. Loach S. A pilot study to stabilize normoglycemia during an educational camp for children and adolescents with type 1 diabetes mellitus. Insulin 2009; 4: 158-68.

18. Winsett RP, Stender SR, Gower G, Burghen GA. Adolescent self-efficacy and resilience in participants attending a diabetes camp. Pediatr Nurs 2010; 36: 293-6.

19. Murphy HR, Wadham C, Rayman G, Skinner TC. Approaches to integrating paediatric diabetes care and structured education: experiences from the Families, Adolescents, and Children's Teamwork Study (FACTS). Diab Med 2007; 24: 1261-8.

20. Stefanowicz A. Stan wiedzy i umiejętności opiekunów dzieci i młodych dorosłych jako czynnik wpływający na występowanie zaburzeń metabolicznych i powikłań cukrzycy typu 1. Gdański Uniwersytet Medyczny, Gdansk 2013

21. Kulaga Z, Rozdzynska A, Palczewska I, et al.; OLAF Study Group. Siatki centylowe wysokości, masy ciała i wskaźnika masy ciała dzieci i młodzieży w Polsce - wyniki badania OLAF. Standardy Medyczne/Pediatria 2010; 7 : 690-700.

22. American Diabetes Association. Standards of medical care in diabetes-2013. Diabetes Care 2013; 36 (Suppl. 1): S1-53.

23. Rosenbauer J, Dost A, Karges B, et al., DPV Initiative and the Garman BMBF Competence Network Diabetes Mellitus. Improved metabolic control in children and adolescents with type 1 diabetes. Diabetes Care 2012; 35: 80-6.

24. International Diabetes Federation, International Society for Pediatric and Adolescent Diabetes. Assessment and Monitoring of Glycaemic Control. Global IDF/ISPAD Guideline for Diabetes in Childhood and Adolescence 2011; 50-9.

25. Mianowska B, Szadkowska A, Pietrzak I, et al. Przekrojowa, jednoośrodkowa ocena wyrównania metabolicznego cukrzycy typu 1 u dzieci na podstawie stężenia HbA1c. Przegl Pediatr 2009; 39: 243-7.

26. Haugstvedt A, Wentzel-Larsen T, Rokne B, Graue M. Psychosocial family factors and glycemic control among children aged 1-15 years with type 1 diabetes: a population-based survey. BMC Pediatrics 2011; 11 (article 118).

27. Araszkiewicz A, Zozulinska-Ziolkiewicz D, Trepinska M, Wierusz-Wysocka B. Knowledge after five-day teaching program in intensive insulin therapy performed at the onset of type 1 diabetes influence the development of late diabetic complications. Diab Res Clin Pract 2008; 81: 61-7.

28. Gawron A, Jarosz-Chobot P, Otto-Buczkowska E. Przyczyny nieprawidłowego wyrównania metabolicznego u młodocianych chorych na cukrzycę typu 1. Lekarz 2010; 1-2: 62-70.

29. Pietrzak I, Bodalski J. Wpływ czynników biologicznopsychologicznych na poziom wiedzy i umiejętności w zakresie samokontroli cukrzycy u dzieci i młodzieży z cukrzycą typu 1. Pediatr Endocrinol Diab Metabol 1999; 5: 63-70.

30. Krishnan S, Short KR. Prevalence and significance of cardiometabolic risk factors in children with type 1 diabetes. J Cardiometab Syndr 2009; 4: 50-6.

31. Russell-Jones D, Khan R. Insulin-associated weight gain in diabetes-causes, effects and coping strategies. Diab Obes Metabol 2007; 9: 799-812.
32. Luczynski W, Szypowska A, Bossowski A, et al. Nadwaga, otyłość i cechy zespołu metabolicznego u dzieci z cukrzycą typu 1. Pediatr Endocrinol Diab Metabol 2010; 16: 83-8.

33. Øverby NC, Margeirsdottir HD, Brunborg C, Dahl-Jørgensen K, Andersen LF; Norwegian Study Group for Childhood Diabetes. Sweets, snacking habits, and skipping meals in children and adolescents on intensive insulin treatment. Pediatr Diab 2008; 9 (part 2): 393-400.

34. Brackenridge B, Swenson K. Discovering diabetes: achieving target blood glucose control through a behavioural approach to insulin and food self-management. Br J Diabet Vasc Dis 2004; 4: 117-20.

35. Pankowska E. Ogólnopolski program leczenia dzieci z cukrzycą typu 1 przy zastosowaniu pomp insulinowych. Med Wieku Rozw 2012; 1: 10-4.

36. Dinneen SF, O'Hara MC, Byrne M, et al.; Irish DAFNE Study Group. The Irish DAFNE Study Protoloc: a cluster randomised trial of group versus individual follow-up after structured education for type 1 diabetes. Trials 2009; 10: 1-10.

37. Lawton J, Rankin D. How do structured education programmes work? An ethnographic investigation of the Dose Adjustment For Normal Eating (DAFNE) Programme for type 1 diabetes patients in the UK. Soc Sci Med 2010; 71: 486-93.

38. Speight J, Amiel SA, Bradley C, et al. Long-term biomedical and psychosocial outcomes following DAFNE (Dose Adjustment For Normal Eating) structured education to promote intensive insulin therapy in adults with sub-optimally controlled type 1 diabetes. Diab Res Clin Pract 2010; 89: 22-9.

39. Hermanns N, Kulzer B, Kubiak T, Krichbaum M, Haak T. The effect of an education programme (HyPOS) to treat hypoglycaemia problems in patients with type 1 diabetes. Diabetes Metab Res Rev 2007; 23: 528-38.

40. Hermanns N, Kulzer B, Krichbaum M, Kubiak T, Haak T. Long-term effect of an education program (HyPOS) on the incidence of severe hypoglycemia in patients with type 1 diabetes. Diabetes Care 2010; 33: 36.

41. Tan MY, Magarey JM, Chee SS, Lee LF, Tan MH. A brief structured education programme enhances self-care practice and improves glycaemic control in Malaysians with poorly controlled diabetes. Health Educ Res 2011; 26: 896-907.

42. Tobiaszewska M, Glowinska-Olszewska B, Luczynski W, Bossowski A. Współczesne metody samokontroli oraz ich zastosowanie u dzieci i młodzieży z cukrzycą typu 1. Probl Pieleg 2011; 19: 557-65.

43. Fendler W, Rizzo $M$, Borowiec $M$, et al. Less but better: cardioprotective lipid profile of patients with GCKMODY despite lower HDL cholesterol level. Acta Diabetol 2014; 51: 625-32.

44. Piłaciński S, Zozulińska-Ziółkiewicz DA. Influence of lifestyle on the course of type 1 diabetes mellitus. Arch Med Sci 2014; 10: 124-34. 